\title{
Innovative energy-saving technology in refrigerated containers transportation
}

\author{
Ludmila Filina-Dawidowicz $(\mathbb{D}) \cdot$ Sergiy Filin
}

Received: 20 July 2017 / Accepted: 29 August 2018 / Published online: 19 September 2018

(C) The Author(s) 2018

\begin{abstract}
The article presents the concept of innovative technology used to store refrigerated containers in port terminals or on ships that aims to reduce the energy consumption. The idea of new technology to store refrigerated containers was described on port's terminal example. According to set assumptions, the mathematical heatbalance model of containers stored on yard has been proposed to calculate the savings, as well as the effects of such solution usage have been shown. The results of preliminary calculations were compared to results of experimental verification conducted in the laboratory and based on the approximate model. Obtained results both calculations and experimental verification proved the effectiveness of proposed concept; however, the experimental results indicate smaller savings, then the calculated one.
\end{abstract}

Keywords Refrigerated container - Energy efficiency . Seaport $\cdot$ Innovative technology $\cdot$ Seal $\cdot$ Cost saving

\section{Introduction}

Since humanity met with the phenomenon of global warming caused by industrial human activities, ${ }^{1}$ the problem of energy consumption reduction is going hand

\footnotetext{
${ }^{1}$ However, a number of worldwide scientists attribute this to cyclical climate change on Earth (Filin and Zakrzewski 2000).

L. Filina-Dawidowicz $(\bowtie) \cdot$ S. Filin

Faculty of Maritime Technology and Transport, West Pomeranian University of Technology, Szczecin, al. Piastów 41,

71-065 Szczecin, Poland

e-mail: ludmila.filina@zut.edu.pl
}

in hand with the problem of $\mathrm{CO}_{2}$ emission decreasing. Nowadays, this problem is the most urgent and fundamental technical problem almost in all branches of engineering and technology (Barbieri and Palma 2017; Duan et al. 2017; European Commission 2016; Łukasik et al. 2015; Tassou et al. 2009). A human being's aspiration to create comfortable conditions for his existence costs a lot: about $17 \%$ of world electricity consumption is related to the operation of refrigeration and air conditioning equipment. Among the expanses on electrical energy consumed in the average family, the rate of refrigerators and air conditioners amounts $18 \%$ of monthly charges (Zakrzewski 2015). The cost structures of cooled and frozen goods transportation does not differ much. Depending on the temperature of transported cargo and external climatic conditions en route, the cooling expanses may vary from 15 to $50 \%$ of transportation charges.

Chilled and frozen goods transportation in refrigerated containers within intermodal transport chains on long distances is performed through seaports and land terminals (Chen and Notteboom 2012; Filina-Dawidowicz and Gajewska 2018). The seaport charges a fee for refrigerated containers services including container connection to the electrical power source on the storage yard (Filina-Dawidowicz and Postan 2015). Taking into account ports tariffs regarding cargo storage, control, and other services, approximate daily fee for cooling one refrigerated container with the cargo in European seaports may rate 50-150 EUR. The number of refrigerated sockets in each port is different, depending on its size and specificity (Table 1). For example, in 2016, the 


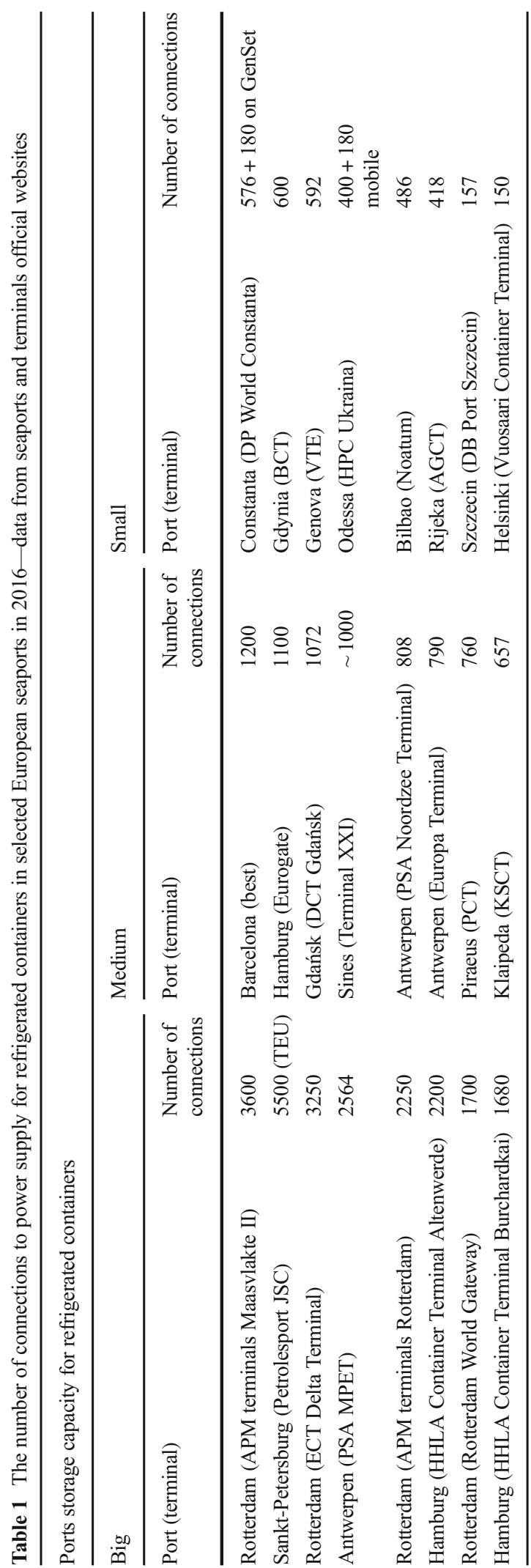

container terminals in Rotterdam seaport had a total number of 18,500 reefer connections (Port Rotterdam 2017).

Depending on guidelines of the manufacturer of container refrigeration unit, its technical condition and the required temperature level in the box, the average power consumption in $40^{\prime}$ container ranges from 6 to $9 \mathrm{~kW}$ (Reefer container 2017). It means that the daily average consumption of electric energy from container will reach $180 \mathrm{kWh}$. In fact, the average consumption per refrigerated container (chilled and frozen) depends on a number of factors including terminal location, weather and storage conditions, container types, and number of units and may vary significantly depending on country (Spengler and Wilmsmeier 2016; Wilmsmeier et al. 2014).

Conducted literature analysis revealed that the issue connected with refrigerated containers transportation efficiency, as well as cost savings during seaports service was widely analyzed. Martins et al. (2017) draw attention to necessity of new model implementations for planning and managing infrastructure of container terminals. Su et al. (2016) indicated strategies that container carriers adopt at hub ports that influence ports vulnerability. In order to improve transportation efficiency Ruiz-Garcia et al. (2007) pointed out intelligent monitoring systems for freight transport in refrigerated containers, traceability issues, IT systems, vehicle location technologies, and radio frequency identification. Defraeye et al. (2015) investigated warm loading of citrus fruit into refrigerated containers for cooling during marine transport instead of forced-air precooling, as a way to achieve several logistical and economic savings. Jedermann et al. (2013) analyzed spatial temperature profile in a container loaded with banana pallets. It was identified that the width of gaps between pallets has the major influence on the spatial temperature profile. The mathematical model to analyze and predict temperature curves in the center of the box was developed.

One of the main problems dealing with refrigerated containers storage and transportation is high level of energy consumption (Fitzgerald et al. 2011). Due to Wilmsmeier et al. (2014), the greatest share of electricity in container terminals seems to be consumed by refrigerated containers for cooling (up to $40 \%$ ), followed by ship-to-shore cranes operation (in terminals where applicable). This share will rise together with increase of time of container stay on the terminal. Therefore, the 
need to reduce the energy consumption of refrigerated container with cooled or frozen cargo is justified. Moreover, it may cause a reduction in transportation cost of goods. This fact may allow both to increase the carrier's/ port's profits and to reduce the wholesale and retail price of goods.

Available literature shows the number of solutions to reduce energy consumption of refrigerated container. These solutions refer, i.e., to adaptation of the terminal layout (Geerlings and van Duin 2011), electrical handling equipment usage (Yang and Lin 2013), and integrated scheduling of cranes and trucks (He et al. 2015). There are solutions that consider the refrigerated container unit operation (Sørensen et al. 2015), searching for energy-saving operation modes.

The size of the electricity consumption of refrigerated container is mostly affected by inevitable heat exchange of container's interior with the environment through the cold-resistant insulation (Filina and Filin 2004). This exchange causes different directions of heat flow through the container insulation in summer and in winter. Preliminary research shows that the share of this component of the heat balance in the overall container balance reaches from 35 to $85 \%$ in cooling mode and up to $50 \%$ in heating mode. Hence, the reduction of such losses in refrigerating containers is not only current and local problem, but also all primary and global-scale problems, connected with environmental friendly technology implementation and reduction of transportation cost of cooled and frozen goods.

In this regard, the moist coating of container, allowing to reduce the escaped heat energy was proposed (Reducing heat 2014). But, this solution is dealt with the number of difficulties, including installation service. This proves that other solutions should be considered.

The article aims to present the innovative concept of storage of refrigerated containers in seaports that allow reducing energy consumption. The concept is justified by experimental investigation.

\section{Research problem analysis}

The service technology of refrigerated containers with cargo is significantly different from containers of other types because of the need to maintain inside the containers' constant microclimatic conditions in every link of the supply chain (Filina-Dawidowicz 2014). Selected dimensions and parameters of the containers are shown in Tables 2 and 3. According to the current regulations (Polski Rejestr Statków 2012; Bonca and Dziubek 1994), refrigerated container unit should operate during its transportation and storage in the storage yard, i.e., the container must be connected to an external power source from the ship or terminal mains or from a separate generator (so-called GenSet). The terminal servicing refrigerated containers usually define a special area, equipped with power supply stations with sockets. One station can serve up to 20 containers, which are plugged using the cables (Fig. 1). Another possibility to link containers to power supply is used in some European ports, where sockets are located on pillars or structures opposite each containers stack. These solutions make terminal personnel easier to reach for cable and allow to reduce the length of power cables, especially for upper layers containers.

After transferring the refrigerated container, e.g., from the quay to the storage area, the container should be connected to the power source as soon as possible. The disconnection of the container within just a few hours can result in load quality loss (Filina and Filin 2004). Refrigerated containers are stored usually in two-three layers. A terminal personnel is obliged to monitor periodically the container operating parameters, including temperature inside the container. Moreover, continuous remote monitoring of microclimate parameters in the refrigerated containers may be applied. World largest container terminals (e.g., Rotterdam, Hamburg, Tokyo) implement this solution.

Containers are stored in ports for several days: 23 days before the loading on ship and up to 7 days after reloading container from ship (depending on port). Containers can be moved on the yard by reach stackers, rail mounted gantry cranes, and rubber-tyred container gantry cranes.

Taking into account containers' location on the storage area (Fig. 2), several container groups could be

Table 2 The selected dimensions of $40^{\prime}$ refrigerated container type HC RF (Maersk line 2017)

\begin{tabular}{lll}
\hline Dimensions, mm & External & Internal (box) \\
\hline Length & 12,192 & 11,583 \\
Width & 2438 & 2292 \\
Height & 2896 & 2545 \\
\hline
\end{tabular}


Table 3 The heat-exchange surface of 40' refrigerated container type HC RF (Maersk line 2017)

\begin{tabular}{|c|c|c|c|c|}
\hline Heat-exchange surface & $\begin{array}{l}\text { External } \\
F_{\text {ex }}, \mathrm{m}^{2}\end{array}$ & $\begin{array}{l}\text { Internal }^{*} \\
F_{\text {in }}, \mathrm{m}^{2}\end{array}$ & $\begin{array}{l}\text { Estimated (geometric mean) } \\
F, \mathrm{~m}^{2}\end{array}$ & $\begin{array}{l}\text { The share of selected surface } \\
\text { in total surface, } \%\end{array}$ \\
\hline Side & $33.94 \times 2$ & $29.48 \times 2$ & 63.26 & 48.36 \\
\hline Floor, roof & $28.55 \times 2$ & $26.55 \times 2$ & 55.06 & 42.09 \\
\hline Door, rear & $7.06 \times 2$ & $5.53 \times 2$ & 12.50 & 9.55 \\
\hline Total & 139.1 & 123.12 & 130.82 & 100 \\
\hline
\end{tabular}

*The depth for refrigeration unit is $472 \mathrm{~mm}$

distinguished. The A group consists of containers, whose three walls (two side and a roof) are surrounded by other containers. They work in lighter conditions than the others, as the share of their sheltered surface in overall surface (in accordance with the data in Table 3) is $69.4 \%$. In addition, these surfaces are not exposed to sunlight. The containers of B group also have three protected walls, but due to the sunlight influence on the roof and adverse direction of heat transfer at the horizontal surfaces, their working conditions are worse. Groups C and D include locations where containers are sheltered only from two sides: the sidewall and the floor and the sidewall and the roof, respectively. The share of sheltered surfaces is about $45.3 \%$. Separately, standing container that does not have sheltered surfaces has the worst working conditions.

\section{The idea of innovative technology and research methodology}

On the basis of observations of the containers operation conducted in seaports, it can be concluded

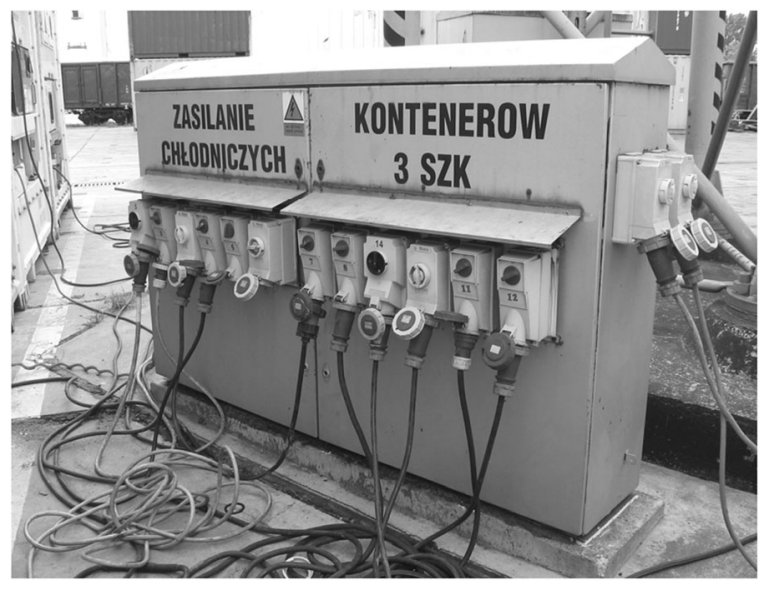

Fig. 1 Station to plug refrigerated containers in Szczecin seaport that depending on the skills of the operator of handling device, the distance S (Fig. 3) between adjacent containers may vary from 20 to $100 \mathrm{~mm}$. Knowing the need to reduce the gap between the containers, operator can place them possibly close to each other reducing the distance up to 30 $40 \mathrm{~mm}$. However, it is still too big distance to exclude natural convection in the gaps between the containers, ${ }^{2}$ e.g., in case of wind absence. Wind blowing causes the temperature in gaps almost the same as in its surrounding. As a result, sheltering the container by other units does not affect the significant reduction of heat transfer of this container with the environment.

In order to gain the benefits, it is proposed to use innovative technology that include gaps isolating from the surrounding air, using elastic strips (seals) installed along the perimeter of each wall of the adjacent containers (Filina-Dawidowicz and Filin 2016).

In order to seal the gap between the containers, several solutions could be implemented. Figure 4 shows two options of such solutions. The strip (seal) can be made as a separate element or group of elements that are installed immediately after containers placement next to each other (Fig. 4a, b) or as an additional equipment of the container (Fig. 4c).

In order to prove the efficiency of the proposed solution, the following research methodology will be used (Fig. 5). The results of preliminary calculations based on heat-balance model of the container will be compared to results of experimental verification based on approximate model conducted in the laboratory. After the results analysis, the conclusions will be drawn.

\footnotetext{
${ }^{2}$ The heat exchange process consists only of the thermal conductivity through the layer of air in very narrow gaps less than $5 \mathrm{~mm}$ wide
} (Фокин 2006). 


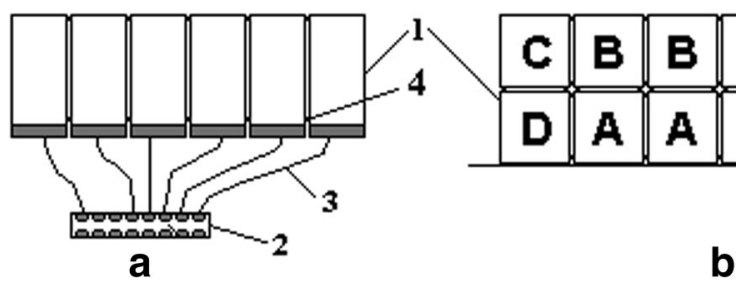

Fig. 2 The scheme of containers location on the storage area, where: a - top view; b - the division of containers depending on their location; 1 -refrigerated container, 2-supply station, 3-cable, and 4-sealing

\section{The concept of calculation model}

\section{Computational model}

In this article, we try to estimate the effects expected from new technology for refrigerated containers storage. For this purpose, simplified balance of a container will be presented.

It is assumed that:

- The air is not removed from the insulated gap.

- A few hours after insulating the gap between containers, the temperature in each isolated gap will be below the ambient temperature.

- Containers are transported to the storage yard by a reach stackers and/or gantry cranes. This technology application allows to place the containers tightly to each other with minor gaps.

- The container door is closed during the service; there is a lack of infiltration, lighting, cargo breathing heat, and people working inside.

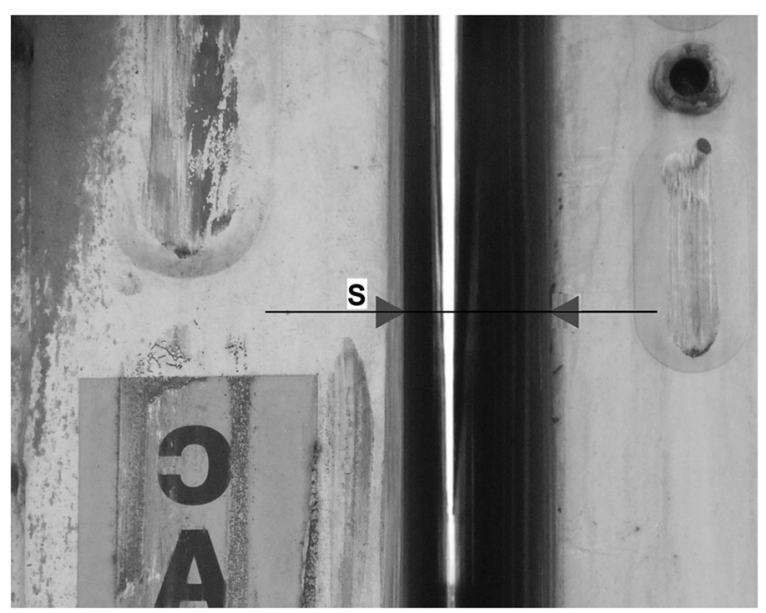

Fig. 3 The gap between the containers in the storage area, where: $\mathrm{S}-$ gap size
The sum of heat gains of the container $\dot{Q}_{\Sigma}$ could be presented in the following way, as shown in Eq. (1):

$\dot{Q}_{\Sigma}=\dot{Q}_{1}+\dot{Q}_{2}+\dot{Q}_{3}+\dot{Q}_{4}$,

where:

$\dot{Q}_{1} \quad$ The sum of heat gains through all walls of the container, [W];

$\dot{Q}_{2} \quad$ The heat stream entering the container due to intended ventilation, [W];

$\dot{Q}_{3} \quad$ The heat stream from fans installed inside the container, [W];

$\dot{Q}_{4} \quad$ The heat stream occurring due to evaporator defrosting, [W].

Taking into account that containers are stored on yard, the heat gains through all walls of the container can be calculated as it is shown in Eq. (2).

$\dot{Q}_{1}=\sum \dot{Q}_{1 \mathrm{i}}=\sum\left(k_{\mathrm{i}} \cdot F_{\mathrm{i}} \cdot \Delta T_{\mathrm{i}}\right)$,

where:

$k_{i} \quad$ Coefficient of heat transfer through the partition;

$F_{\text {i }} \quad$ The surface area of heat transfer;

$\Delta T_{\mathrm{i}} \quad$ The difference between average temperatures of the air inside the container and in the gap.

Then, we calculate the heat stream flowing into container as shown in Eq. (3) during intended ventilation:

$\dot{Q}_{2}=n V\left(\rho_{\mathrm{z}} h_{\mathrm{z}}-\rho_{\mathrm{w}} h_{\mathrm{w}}\right) \frac{1}{3.6 \times 24}$,

where:

$n \quad$ The number of air exchange in the container box per day, for frozen fish $n=2$;

$V \quad$ The box volume $\left[\mathrm{m}^{3}\right], V=67.4 \mathrm{~m}^{3}$;

$\rho_{\mathrm{w}} \quad$ Air density in the box $\left[\mathrm{kg} / \mathrm{m}^{3}\right]$, in case of fish carried in the container box at the temperature of- 


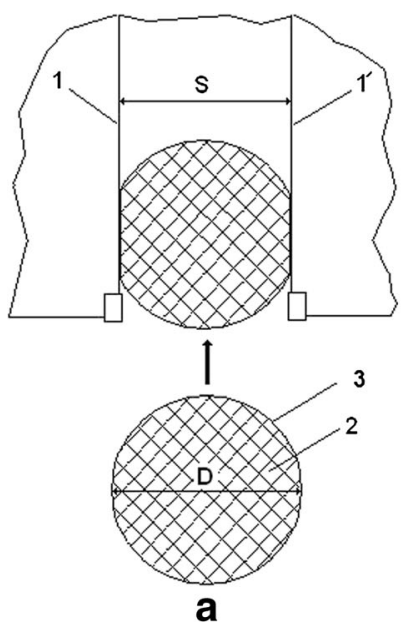

Fig. 4 Selected options of refrigerated containers seals, where: $\mathbf{a}$ - seal as flexible foam rod, $\mathbf{b}$ - seal as rubber tube, and $\mathbf{c}-$ seal as inner inflatable tube as a part of container: 1 - container wall,

$20{ }^{\circ} \mathrm{C}$ and relative humidity of $90 \%, \rho_{w}=1.39 \mathrm{~kg} /$ $\mathrm{m}^{3}$;

$\rho_{\mathrm{z}} \quad$ Ambient air density $\left[\mathrm{kg} / \mathrm{m}^{3}\right]$, for the summer period in the case of the temperature of $+20^{\circ} \mathrm{C}$ and relative humidity of $75 \%, \rho_{z}=1.20 \mathrm{~kg} / \mathrm{m}^{3}$;

$h_{\mathrm{z}} \quad$ Specific enthalpy of air entering the box $[\mathrm{kJ} / \mathrm{kg}]$, $h_{z}=47.78 \mathrm{~kJ} / \mathrm{kg}$;

$h_{\mathrm{w}} \quad$ Specific enthalpy of air in the box $[\mathrm{kJ} / \mathrm{kg}], h_{w}=$ $-18.38 \mathrm{~kJ} / \mathrm{kg}$.

The third component of the balance $Q_{3}^{\cdot}$ is dependent on the number of cooling fans in container. It is assumed that $100 \%$ of fans electric power remains in the box and ultimately converted into heat.

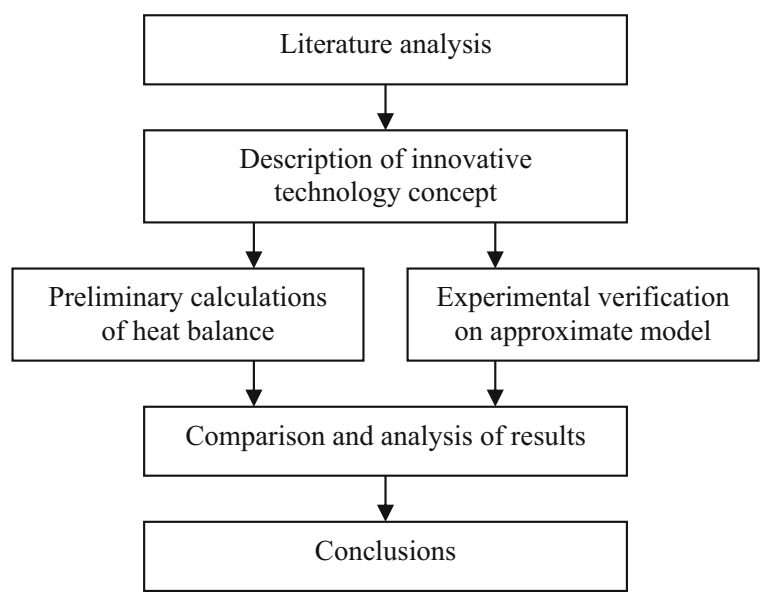

Fig. 5 Methodology of research

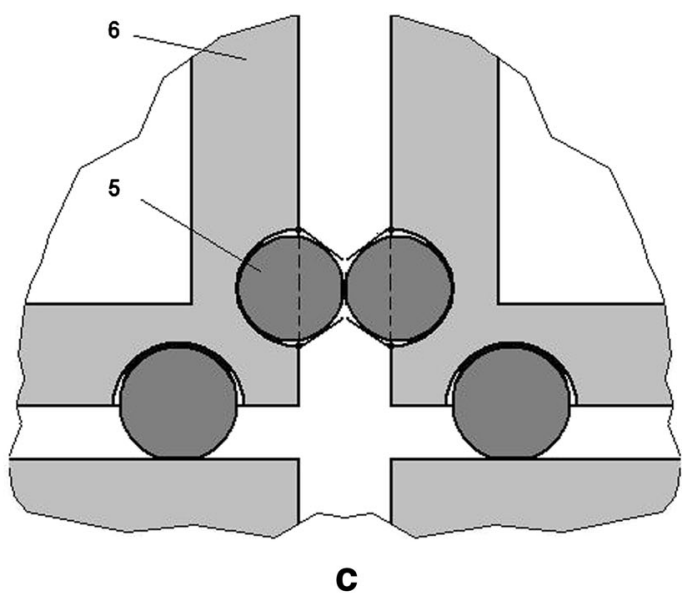

2-foam seal, 3-seal's cover, 4 - rubber seal, 5-inner inflatable seal, 6 - container's insulation, D — diameter, and S - gap between the containers

The evaporators of refrigerated boxes, in which the refrigerant evaporates at the temperature below $-2 \ldots$ $-4{ }^{\circ} \mathrm{C}$, should be periodically defrosted, using the heat. The frequency and duration of defrost cycles depend on the frosting intensity and refrigerant evaporating temperature. Two main methods of containers defrosting are known using refrigerant in state of hot gas in reverse circulation mode and by means of electric heaters (Zakrzewski 2007). For the calculations, we choose the less energy-saving method, mainly the usage of heaters, to prevent artificial increase of $\dot{Q}_{1}$ share.

To calculate the relevant balance component as shown in Eq. (4), let us use the equation proposed by Zakrzewski (2007), which takes into account the defrosting efficiency $\eta_{\text {od }}$.

$\dot{Q}_{4}=n P_{\mathrm{gr}}\left(1-\eta_{\mathrm{od}}\right) \frac{\tau_{\mathrm{od}}}{24}$,

where:

$n \quad$ Number of heaters;

$P_{\mathrm{gz}} \quad$ Electrical power of particular heater, [W];

$\eta_{\text {od }}$ Defrosting efficiency, $\eta_{\text {od }}=0.25$ (Zakrzewski 2007);

$\tau_{\text {od }}$ Total defrosting time, hours per day.

In order to obtain a value of heat load reduction under real conditions of container operation, it is necessary to determine the air temperature in each insulated gap. For 
a selected gap, this value can be determined by the heat balance of the single gap as shown in Eq. (5):

$\sum_{1}^{2} \dot{Q}_{\mathrm{C}}=\sum_{1}^{4} \dot{Q}_{\mathrm{S}}$

where:

$\sum_{1}^{2} \dot{Q}_{\mathrm{C}} \quad$ The sum of heat streams through the insulation of two adjacent containers;

$\sum_{1}^{4} \dot{Q}_{\mathrm{S}} \quad$ The sum of heat streams from the environment through the seal, located in each of four edges of container wall.

During calculation of $\dot{Q}_{\mathrm{S}}$, two streams should be taken into account:

- The stream going directly through the seal, considering it as multi-layered insulation,

- The stream of longitudinal thermal conductivity in the container steel walls in parts of adjoining the seal to the wall.

To make the computational model sufficiently accurate, it is necessary to consider the dependence of the thermal conductivity coefficient of the seal material on the degree of its deformation, which is a very difficult task due to the lack of available research results in this field. The development of such models will be a subject of our further research.

\section{Calculation results}

Further analysis relates to following conditions of containers service on the storage yard:

- $40^{\prime}$ containers filled with the same product (e.g., frozen fish) are transported in the same temperature $-20{ }^{\circ} \mathrm{C}$,

- The service is carried out in summer, the temperature outside $t_{\mathrm{ot}}=20{ }^{\circ} \mathrm{C}$, as the average daily temperature in Odessa seaport in August,

- The temperature $t_{\mathrm{s}}$ is the same in all gaps and average value of the temperature $t_{\mathrm{k}}$ in the container and the ambient temperature $t_{\mathrm{ot}} ; t_{\mathrm{s}}=0{ }^{\circ} \mathrm{C}$,

- Selected container is equipped with three internal cooling fans of $250 \mathrm{~W}$ powers each.

- In order to calculate the savings heat balance for refrigerated containers, storage in yard is considered and two variants of heat balance are analyzed:
- Heat balance without insulating the gaps between the containers,

- Heat balance using the seals between the containers.

The calculations have been carried out for each mentioned heat streams. Due to the current literature (e.g., Polski Rejestr Statków 2012), it is recommended to use the maximum value of the global heat transfer coefficient in approximate calculations of the containers. In accordance with these requirements $k_{\max }$ is equal $0.4 \mathrm{~W} / \mathrm{m}^{2} \mathrm{~K}$.

The results of the calculations $Q^{\circ}{ }_{1 \mathrm{i}}$, according to Eq. (4), for individual walls of the container for the cases with and without gaps are given in Tables 4 and 5. The other balance components are the same for the compared variants.

On the basis of the assumptions, the calculated value $Q_{2}^{*}$ reaches $129.3 \mathrm{~W}$. Taking into account that the selected refrigerated container is equipped with three internal cooling fans (the power of each fan is $250 \mathrm{~W}$ ), the third component of the balance is $Q_{3}^{\cdot}=3 \times 250=$ 750 W. $Q_{4}{ }_{4}$ was calculated using Eq. (4). The calculation results of all heat-balance components for two analyzed options are shown in Table 6.

As far as assumptions are concerned, for container type A operating at the determined mode, the calculated energy efficiency is more than $23 \%$. For the group of containers stored in two layers, as shown in Fig. 2, the total savings will amount from 15 to $16 \%$ (for 6 containers) up to $20-21 \%$ (for 12 containers). It means that the temperature reduction of one degree in the gap between the containers' results in reduction of energy consumption on the average of $1 \%$. Reduce of $Q_{1}^{*}$

Table 4 Comparison of calculation results $\dot{Q}_{1 \mathrm{i}}$ for particular walls of the container from the group A, without gaps sealing

\begin{tabular}{lllll}
\hline Container's wall & $F, \mathrm{~m}^{2}$ & $t_{\mathrm{z}},{ }^{\mathrm{o}} \mathrm{C}$ & $\Delta T, \mathrm{~K}$ & $\dot{Q}_{1 \mathrm{i}}, \mathrm{W}$ \\
\hline Sidewall I & 31.63 & 20 & 40 & 506.1 \\
Sidewall II & 31.63 & 20 & 40 & 506.1 \\
Roof & 27.53 & 20 & 40 & 440.5 \\
Floor & 27.53 & $20^{*}$ & 40 & 440.5 \\
Front side (door) & 6.25 & 20 & 40 & 100.0 \\
Rear side (refrigeration unit) & 6.25 & $30^{* *}$ & 50 & 125.0 \\
Total & 130.82 & - & - & 2118.2 \\
\hline
\end{tabular}

*The temperature of storage area surface is equal to the ambient temperature

**The temperature in refrigeration unit is in average of $10 \mathrm{~K}$ above the ambient temperature due to the heat generated by a compressor, condenser, and other devices 
Table 5 Comparison of calculation results $\dot{Q}_{1 \mathrm{i}}$ for particular walls of the container from the group A, with gaps sealing

\begin{tabular}{lllll}
\hline Container's wall & $F, \mathrm{~m}^{2}$ & $t_{\mathrm{z}},{ }^{\circ} \mathrm{C}$ & $\Delta T, \mathrm{~K}$ & $\dot{Q}_{1 \mathrm{i}}, \mathrm{W}$ \\
\hline Sidewall I & 31.63 & 0 & 20 & 253.0 \\
Sidewall II & 31.63 & 0 & 20 & 253.0 \\
Roof & 27.53 & 0 & 20 & 220.3 \\
Floor & 27.53 & 20 & 40 & 440.5 \\
Front side (door) & 6.25 & 20 & 40 & 100.0 \\
Rear side (refrigeration unit) & 6.25 & 30 & 50 & 125.0 \\
Total & 130.82 & - & - & 1391.9 \\
\hline
\end{tabular}

component shares in overall balance results in proportional decrease of savings.

The less favorable situation of new technology application takes place, for example, for the case of bananas transportation in $20^{\prime}$ container in temperature of + $13.0^{\circ} \mathrm{C}$. In such case, the savings related to gaps insulation will decrease to 5-6\%. This case will require additional analysis of new technology profitability before its implementation.

On the other hand, it can be expected that the correct choice of seal type and its placement will cause the stabilization of actual average temperature in the gap only on $3-5{ }^{\circ} \mathrm{C}$ higher in comparison to the temperature inside the containers. In this case, for analyzed conditions of container service, the amount of savings will increase to $35-40 \%$.

\section{Experimental verification of the technology}

The object of research

Experimental verification of the described technology directly in the storage yard at the port is a complicated

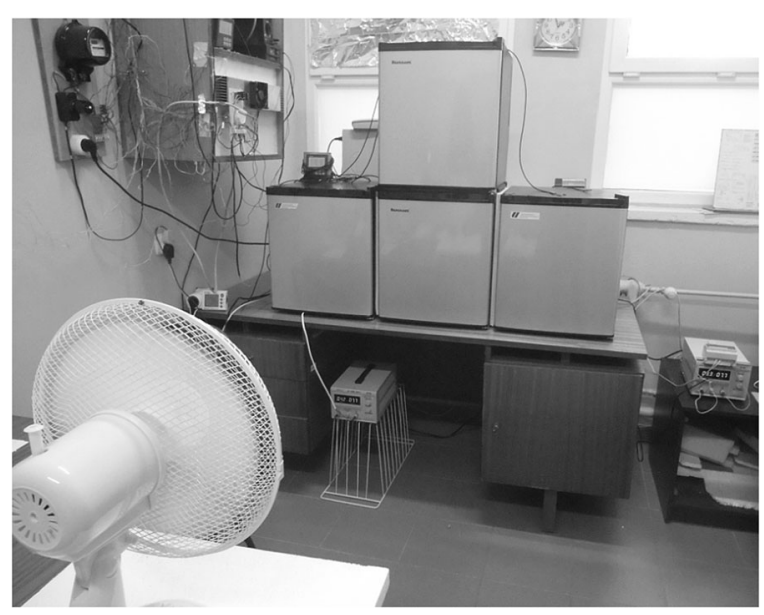

Fig. 6 Installation of research object

and an expensive process. The approval and participation of representatives of carrier (or forwarding company) and terminal operator are necessary for its execution. Moreover, this test should be preceded by comparative analysis of calculated efficiency of the different variants of seals usage that will be the topic of our further research. Therefore, the present stage of technology development was verified on the approximate model by test conducted in the laboratory using four refrigerators (Fig. 6).

As the objects of research, four empty similarly designed thermoelectric refrigerators Ravanson LK-48 were used, each of a volume of 481 . Refrigerators were put on the desk like refrigerated containers in the storage area (compare Figs. 2 and 6). The analysis was carried out for one centrally installed refrigerator - the so-called controlled refrigerator. Two refrigerators were converted into DC power supply, and thermostats of other chambers were adjusted to perform continuous operation and to set similar temperature inside all refrigerators.

Table 6 Calculation results of heat-balance components for analyzed options

\begin{tabular}{|c|c|c|c|c|c|}
\hline $\begin{array}{l}\text { Heat-balance } \\
\text { components }\end{array}$ & $\begin{array}{l}\text { Heat stream in } \\
\text { basic variant } \\
\text { (without seals), W }\end{array}$ & $\begin{array}{l}\text { The share of component in } \\
\text { the balance (basic variant), } \%\end{array}$ & $\begin{array}{l}\text { Heat stream in } \\
\text { new variant } \\
\text { (with seals), W }\end{array}$ & $\begin{array}{l}\text { The share of component in } \\
\text { the balance (new variant), \% }\end{array}$ & Load reduction, $\%$ \\
\hline$\dot{Q}_{1}$ & 2118.2 & 67.8 & 1391.9 & 58.1 & 34.29 \\
\hline$\dot{Q}_{2}$ & 129.3 & 4.2 & 129.3 & 5.4 & 0 \\
\hline$\dot{Q}_{3}$ & 750.0 & 24.0 & 750.0 & 31.3 & 0 \\
\hline$\dot{Q}_{4}$ & 125.0 & 4.0 & 125.0 & 5.2 & 0 \\
\hline$\dot{Q}_{\Sigma}$ & 3122.5 & 100 & 2396.2 & 100 & 23.26 \\
\hline
\end{tabular}


Such type of refrigerators was selected due to the following reasons:

- Continuous unit operation is consistent with operation mode of refrigerated container in which the temperature inside is maintained with an accuracy of $+0.1 \div 0.3 \mathrm{~K}$,

- Housing of refrigerators, including door hinges design, allows to set them with a distance of 12 $16 \mathrm{~mm}$, the width of this gap is $3-4 \%$ of refrigerator width, that is, similar to the corresponding indicator for refrigerated container,

- Availability of models.

It is necessary to pay attention on the fact that there are obvious differences in the size ratio of refrigerated containers and selected refrigerators. The refrigerator is several times shorter than the container, which means that the proportion of the sidewalls, roof, and floor is substantially smaller (Table 7). Nevertheless, let us try to estimate the effects of the gaps insulation between the refrigerators, analyzing the operation of the controlled refrigerator.

Surfaces of sidewalls and roof of controlled refrigerator will be isolated from the environment using the seals between refrigerators standing next to it and above.

On the basis of data presented in Table 7, it can be concluded that the share of refrigerator heat-exchange surface, isolated from the environment, is $48 \%$, while in the container, this value reaches $69.4 \%$, i.e., almost 1.5 times more. But in the refrigerator, two of the four components of the container heat balance, named $\dot{Q}_{2}$ and $\dot{Q}_{4}$, do not take place; moreover, the component $\dot{Q}_{3}$ reaches about $1 \mathrm{~W}$, i.e., it does not exceed at 3-5\% of component $\dot{Q}_{1}$. Therefore, it can be stated that dimensions ratio may not have a decisive influence on the result of comparative research.
Let us consider other diversities. Thermoelectric refrigerator is able to achieve a temperature difference between the environment and chamber about 15-20 K (Filin and Chmielowski 2015; Balva et al. 2017). In our case, it is about $16 \mathrm{~K}$. For analyzed refrigerated containers, the difference can reach $40 \mathrm{~K}$. Therefore, in the planned experiment, the positive effect of gaps insulation will be significantly lower.

The fan is used to simulate the real conditions as in the storage yard. Its efficiency is enough to emit a weak or moderate wind, but it limits the comparability of the model with real conditions.

Taking into consideration that determining the exact quantitative correlation of the results received by the calculation model and experiment was not the purpose of this study; without any doubt, it could be stated that a result of experiment will form the small part (below $30 \%$ ) of the real savings.

The research was conducted for five options following refrigerator operations:

(1) One free-standing refrigerator;

(2) Set of four refrigerators without gaps insulation and without forced-air flow;

(3) Set of four refrigerators with gaps insulation and without forced-air flow;

(4) Set of four refrigerators without gaps insulation and with artificial air flow (wind simulation);

(5) Set of four refrigerators with gaps insulation and with artificial air flow (Fig. 6).

The research aimed to determine the differences between five analyzed options of refrigerator operations in terms of temperature inside the controlled refrigerator and the temperature in gaps and energy consumption. For each presented options, the experiment was repeated three times, then the results were averaged.

Table 7 Selected parameters of the refrigerator type Ravanson LK-48

\begin{tabular}{|c|c|c|c|c|}
\hline The area of heat exchange, $\mathrm{m}^{2}$ & $\begin{array}{l}\text { External } \\
F_{\mathrm{z}}\end{array}$ & $\begin{array}{l}\text { Internal } \\
F_{\mathrm{w}}\end{array}$ & Calculated (geometric mean) $F$ & $\begin{array}{l}\text { The share of selected surface } \\
\text { in the overall surface, } \%\end{array}$ \\
\hline Sidewall & $2 \times 0.185$ & $2 \times 0.129$ & 0.310 & 33 \\
\hline Roof & 0.166 & 0.112 & 0.136 & 15 \\
\hline Floor & 0.166 & 0.112 & 0.136 & 15 \\
\hline Door, rear side & $2 \times 0.207$ & $2 \times 0.149$ & 0.352 & 37 \\
\hline Total & & & 0.934 & 100 \\
\hline
\end{tabular}

*The depth for the refrigeration unit is $80 \mathrm{~mm}$ 
During the tests, the following parameters were measured:

- The temperature in all chambers, the ambient temperature, the temperature of the hot (outside) radiator in the controlled refrigerator, and the temperature of the air in the gaps between refrigerators in the lower layer,

- Electrical parameters of refrigerators power supply, including electric current and voltage supply for the case of alternating and constant current, energy and power consumption etc.,

- The air velocity at the selected measuring points,

- Time (during start-up phase data reading was performed every $5 \mathrm{~min}$, in a fixed mode every $15 \mathrm{~min}$ ).

In order to measure the abovementioned parameters, the following equipment was used:

- Two 8-channel temperature meters type AR205, connected with thermocouples type J (Fig. 7a). The resolution of the device for temperature measurement reaches $0.1 \mathrm{~K}$,

- Two electronic multifunction power consumption meters DC type FRER C15UCL (Fig. 7b) with a resolution of $1 \mathrm{Wh}$,

- Two electronic multifunction electric power consumption meters AC type Energy Logger 3500 (Fig. 7c) with a resolution of $1 \mathrm{Wh}$.

All measurements were carried out in accordance with the recommendations of the following standards: PN-91-75051, PN-EN ISO 7371 for refrigerators with climatic class N, EN ISO 8561:1995 + A1:1997, and
PN-EN ISO 62552:2013-07. Verification of temperature measurement was performed using digital temperature devices: 10-channel ЦР7701-02 meter working with thermocouples type L, and single-channel ЦР7702 meter cooperating with thermistors with the standard resistance of $50 \Omega$. Both devices have 0.05 accuracy class for temperature resolution measurement of $0.1 \mathrm{~K}$. The detailed information about devices and research methodology is described in papers (Filin and Chmielowski 2015; Filin and Jasińska 2013; Jasińska and Filin 2012).

Power supply of two refrigerators with constant current was carried out by device type D3010. Three-speed fan type HB DF 3001 capt the air movement. Temperature stability in the laboratory was provided by the air conditioner Sanyo model SAP KR(CR)127EHAX.

The air speed (for options 4 and 5) was measured at nine points using anemometer CHY361, including 1-m distance from the fan, at controlled refrigerator door and in the gaps. The monitoring system schemes that indicate the position of the temperature probes and air speed measurement points are shown in Figs. 8 and 9.

After performing the tests without insulation of gaps between refrigerators, the side walls were insulated on both sides with window rubber D-shaped seals, size $13 \times 10 \mathrm{~mm}$ (Fig. 10). The insulation of the gaps between the lower and upper refrigerators was carried out using a rubber cover.

All experiments were conducted at constant ambient temperature of $25 \pm 0.3{ }^{\circ} \mathrm{C}$. The ambient temperature fluctuations have been considered through the calculation of a temperature difference between the environment and the average temperature in the chamber (Table 8, column 3).

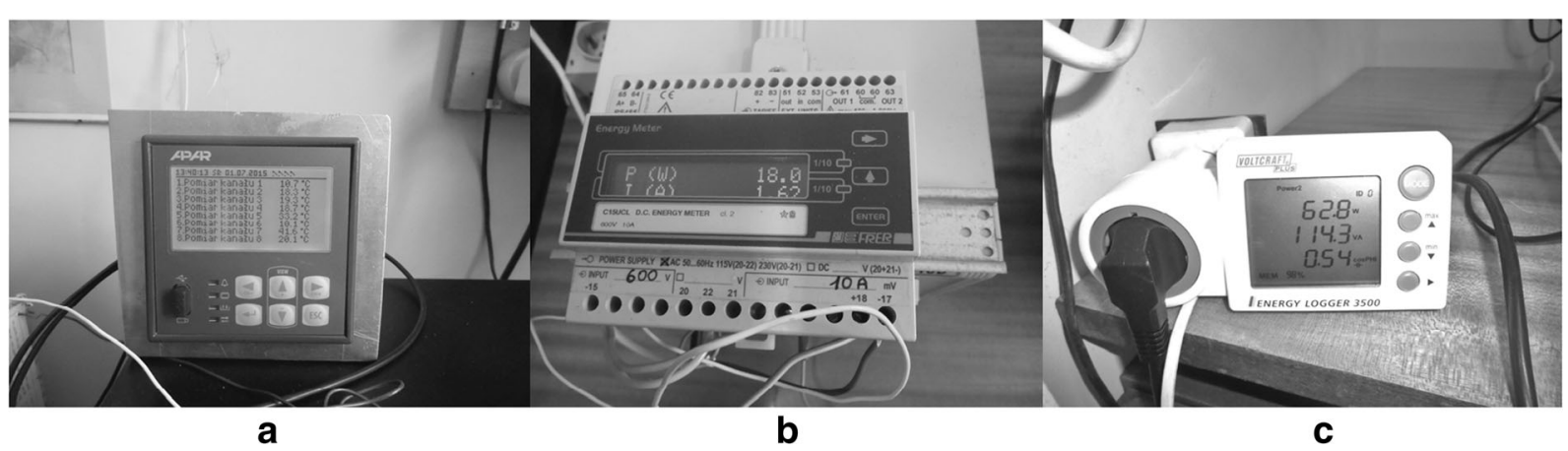

Fig. 7 The monitoring system devices, where: $\mathbf{a}$ - temperature meter, $\mathbf{b}$ - electronic multifunction power consumption meter DC, and $\mathbf{c}$ - electronic multifunction electric power consumption meters AC 


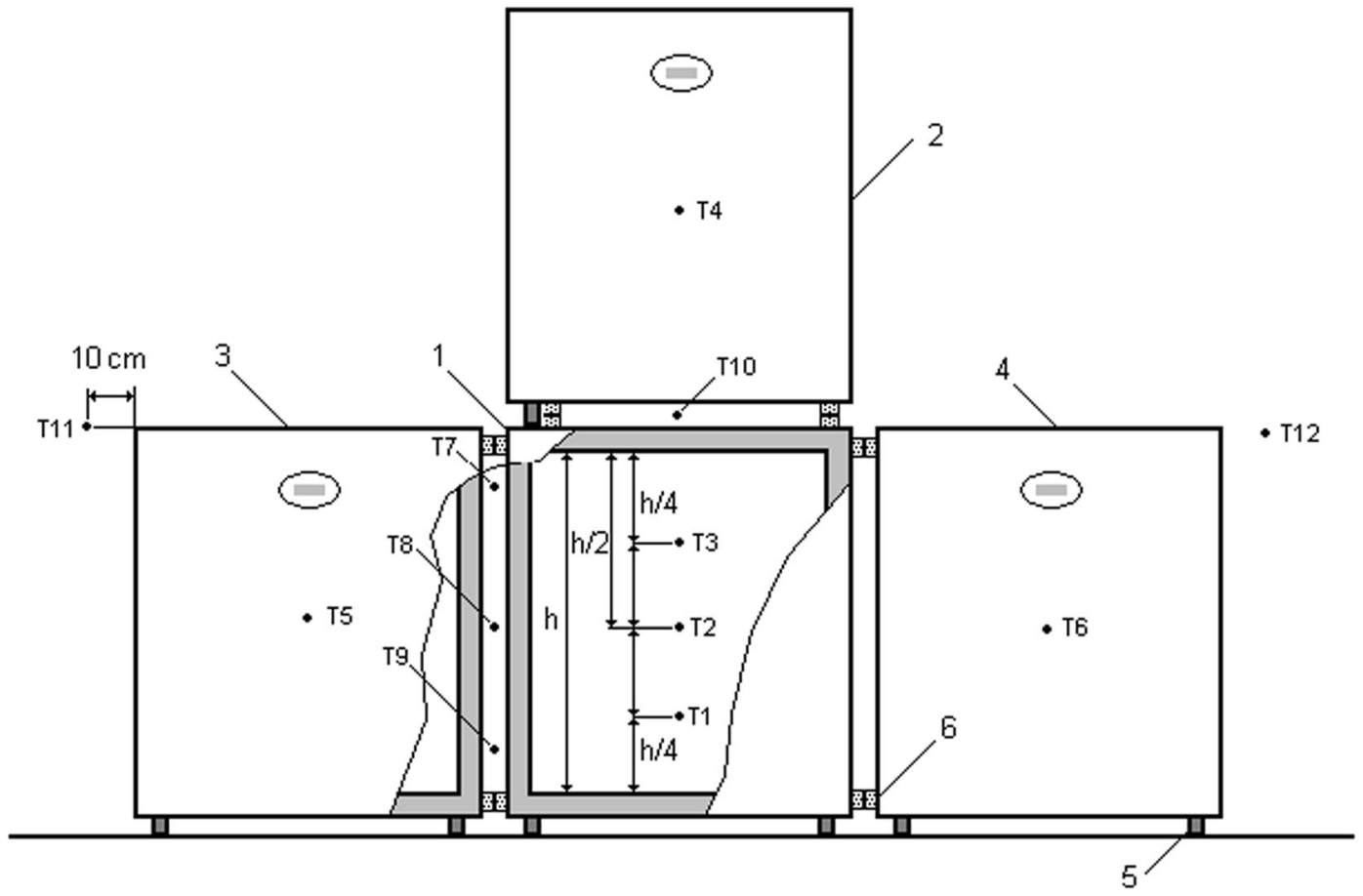

Fig. 8 The monitoring system scheme for temperature measurement, where: 1 -controlled refrigerator, 2-4-adjacent refrigerators, 5-leg of refrigerator, 6-rubber seal, T1-T3 - temperature probes installed inside the controlled chamber, T4-T6 - temperature probes installed in the geometric center of the adjacent

The results of the experiment

Selected results of the experimental research are given in Table 8. Presented data refers to the working conditions obtained at $3-3.5 \mathrm{~h}$ after turning on the refrigerators. During the experiment execution for options 2 and 4 , the temperature inside the chambers of refrigerators surrounding the controlled refrigerator was not more different than $1 \mathrm{~K}$ from the average temperature in chamber of the controlled refrigerator (column 2 of Table 8). For options 3 and 5, the same temperatures were kept in all chambers.

Significant reduction of temperature in the chamber of controlled refrigerator surrounded by refrigerators with similar internal temperature compared to freestanding refrigerator has been observed. In options 2 and 4, i.e., without gaps insulation, this decrease about $1 \mathrm{~K}$, while in options 3 and 5 with insulated gaps: about 1.4$1.9 \mathrm{~K}$.

The positive effect of gaps insulation between refrigerators has been confirmed experimentally; however, it was not as significant as the calculated one. It can be refrigerators, T7-T9 - temperature probes inside the insulated vertical gap, T10 - temperature probe in the geometric center of the insulated horizontal gap, T11 and T12 - temperature probes for outside temperature measurement, and $\mathrm{h}$ - chamber height

explained mainly by the fact that the emission of warm air in the thermoelectric refrigerator takes place towards lateral sides, but in containers - perpendicularly to the frontal plane of the container. The flow of warm air leaving the radiator of the thermoelectric refrigerator (its temperature is on average of $10 \mathrm{~K}$ above the ambient temperature) collides with the airflow of the refrigerator standing next to it. As a result, the part of the common stream impacts on the side walls of both refrigerators, reducing the positive effect of gaps insulation.

The positive effect of gaps insulation is proved by a reduction of the average temperature in the chamber in conditions of its stabilization absence. Literature data, e.g., (Правила расчета 2014) reveals that each degree of lowering the temperature in the refrigerating chamber in the temperature range from +10 to $-30{ }^{\circ} \mathrm{C}$ absorbs on the average $4 \%$ of additional energy consumption. Based on these data, the reduction of power consumption of the controlled refrigerator was estimated (Table 8).

Experimental research indicates existing but weak influence of air movement on the effectiveness of gaps insulation solution. Final conclusions about wind 


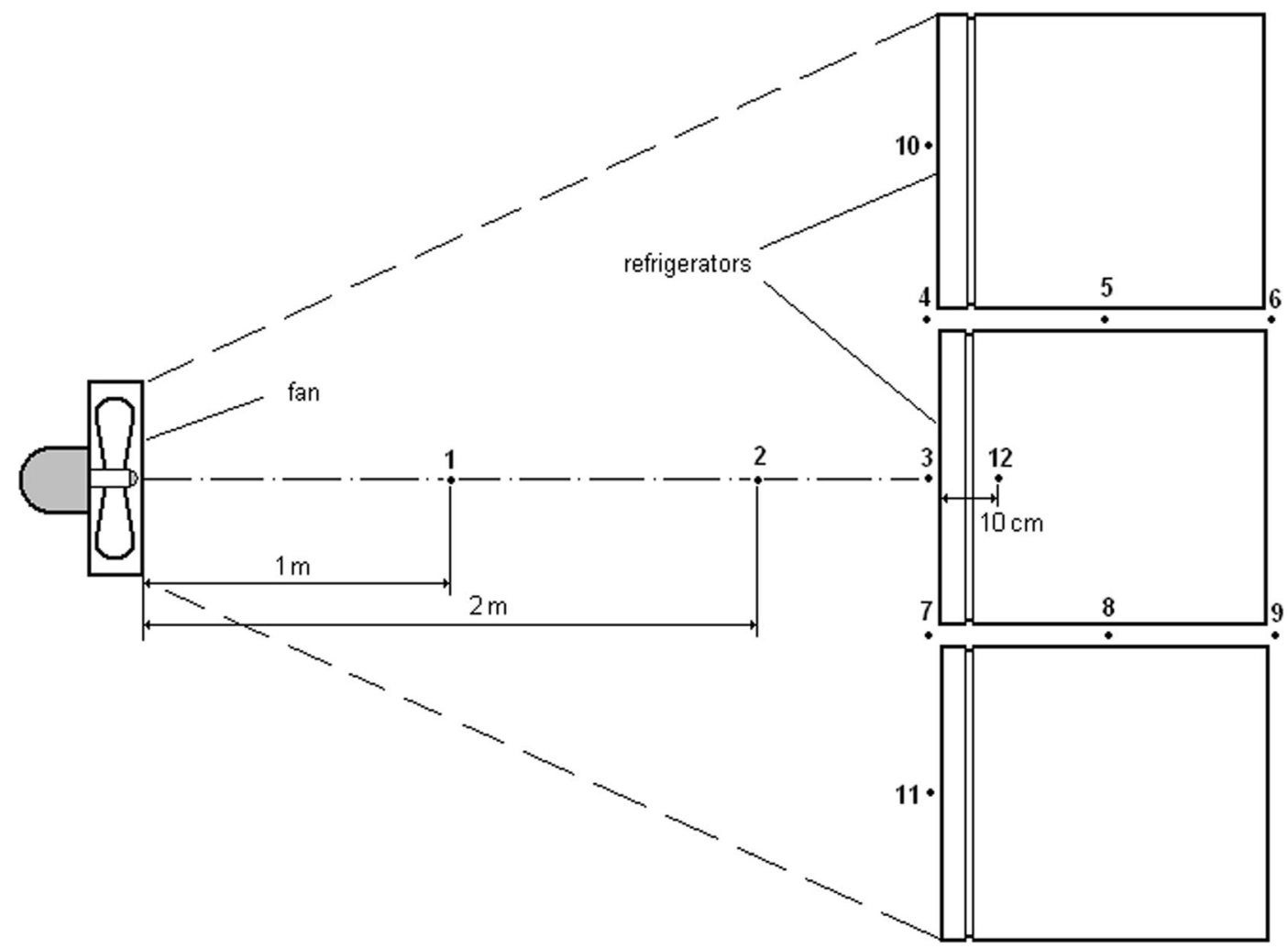

Fig. 9 The monitoring system scheme for air speed measurement (view from the top), where: 1-11 - air speed measurement points located in the mid-height of refrigerators and 12 - air speed measurement point located $5 \mathrm{~cm}$ above the top surface of the refrigerator

influence on energy savings during new technology implementation can be brought on the basis of research carried out on a real object.

Nevertheless, achieved experimental results prove the existence of a positive effect of gaps insulation between the containers stored on yard. Assuming that the reduction of power consumption is proportional to the temperature difference between environment and

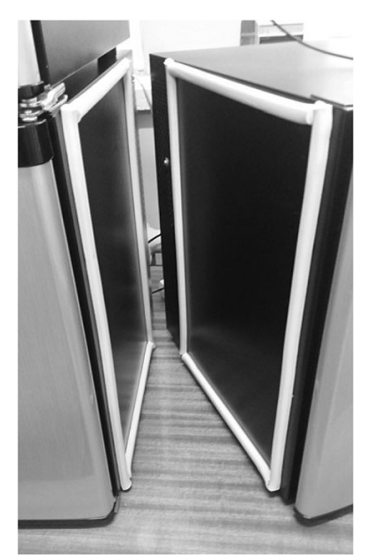

Fig. 10 Sidewalls of the refrigerators equipped with rubber seals chamber, it could be calculated that for temperature difference of $40 \mathrm{~K}$, the reduction of energy consumption will reach $18.2 \%$.

\section{Discussions}

This article introduces the concept of new innovative energy-saving approach that will be developed in future. Implementation of the described new technology may take place during different links of refrigerated containers supply chain (sea and dry ports, container ships, intermodal terminals, logistics centers etc.). Its most efficient usage seems to be both in small and large seaports (e.g., Rotterdam, Hamburg, Los Angeles, Hong Kong) and in perspective on ships, especially crossing long distances, e.g., on such routes as: South AmericaChina and Africa-Northern Europe. It may be deployed by container alliances, container carriers/forwarders, and global container terminals as a way to reduce energy consumption. The discussions carried out with several small seaports, which revealed that container terminals 
Table 8 Selected results of the experimental research at ambient temperature of $25^{\circ} \mathrm{C}$

\begin{tabular}{llllll}
\hline $\begin{array}{l}\text { Options of refrigerators } \\
\text { working conditions }\end{array}$ & $\begin{array}{l}\text { The average } \\
\text { temperature in } \\
\text { the chamber, }{ }^{\circ} \mathrm{C}\end{array}$ & $\begin{array}{l}\text { The temperature } \\
\text { difference between } \\
\text { the environment } \\
\text { and chamber, } \mathrm{K}\end{array}$ & $\begin{array}{l}\text { The average } \\
\text { power } \\
\text { consumption, } \mathrm{W}\end{array}$ & $\begin{array}{l}\text { The average } \\
\text { air temperature } \\
\text { decrease in the } \\
\text { gaps*, } \mathrm{K}\end{array}$ & $\begin{array}{l}\text { The estimated reduction } \\
\text { of energy consumption, } \%\end{array}$ \\
\hline 1 & 10.2 & 14.8 & 62.3 & - & - \\
2 & 9.4 & 15.8 & 61.6 & 0.2 & 4 \\
$3 * *$ & 9.0 & 16.2 & 61.4 & 1.4 & 6.4 \\
4 & 9.2 & 15.9 & 61.3 & 1.8 & 7.6 \\
$5 * *$ & 8.6 & 16.7 & 61.0 & 0 & 4.4 \\
\hline
\end{tabular}

*In relation to the ambient temperature

**Options with insulated gaps

are interested in energy consumption reduction. Therefore, this technology introduction may become a part of ports/container terminals energy saving and/or innovation development strategy.

It is important to mention that the containers stored in the port terminal or on ships are subjected to the action of solar radiation. Insulation of gaps between the sidewalls and roof/floor of adjacent containers does not change the fact that the door and rear side are subjected to such radiation, which absorbed by the metallic surfaces is transferred by thermal conduction in the metallic sheet. It subsequently exchanges the heat with the air inside and outside the refrigerated boxes of adjacent containers. Moreover, the temperature outside and inside the containers is influencing the heat exchange. The heat flow will be analyzed by us in our future publications.

The seals used for gaps insulation could be made of different materials, e.g., rubber or elastic polyester, inflatable tube systems could be applied, fixed, or removal solutions may be used. Each solution has its advantages and drawbacks that should be studied in more details.

The implementation of gaps insulation between containers in seaports and on ships may be carried out in different ways, e.g., it could be based on automotive solutions in combination with information technology usage. Nevertheless, new technology implementation causes the number of questions that should be answered, i.e, how to organize the process of new technology implementation in seaport? What kind of insulation solution would be more efficient? In order to answer these questions, presented concept investigation should be continued and experimental verification on real containers at seaport should be carried out.

\section{Conclusions}

A new technology for servicing the group of refrigerated containers with cargo on the yards and on ships was introduced. The technology is based on insulation of gaps between the adjacent containers from the environment using elastic seals. The use of new technology can significantly reduce the energy consumption of refrigerated containers without interfering into the design of the container box or a refrigeration unit and without changing its operating mode.

Preliminary research and conducted calculations show that the maximum level of reduction of energy consumption by containers from the analyzed group A is $35-40 \%$. For the selected case, the savings achieved more than $23 \%$. The quantitative correlation between the air temperature in insulated gaps and energy consumption reduction was determined.

The experimental verification of the technology was carried out on approximate model in the laboratory. The aim of the experiment was to verify and confirm the fact that the gaps insulation leads to lower the temperature inside the insolated gap, which allow to decrease the energy consumption. The tests and comparative analysis justified the existence of a positive effect of proposed technology. The measured reduction of energy consumption was $7.6 \%$. Regarding this, it could be stated that the efficiency of this technology will highly depend on seal tightness and the effect of gaps insulation will be the bigger, more containers will be on container terminal.

The obtained results indicate the need for further work, particularly the development of heat transfer model in an insulated gap, selection of the most effective seals and the methods of their installation and/or 
mounting, and feasibility and savings analysis. Moreover, the subject of future research will cover determination of the boundary conditions of economic efficiency of the new technology implementation, taking into account the containers dwell time in storage yard or transportation time on ship. The ultimate goal is to implement the proposed technology in ports and on ships.

Acknowledgements This work has been supported by the West Pomeranian University of Technology, Szczecin, Poland.

\section{Compliance with ethical standards}

Conflict of interest The authors declare that they have no conflict of interest.

Open Access This article is distributed under the terms of the Creative Commons Attribution 4.0 International License (http:// creativecommons.org/licenses/by/4.0/), which permits unrestricted use, distribution, and reproduction in any medium, provided you give appropriate credit to the original author(s) and the source, provide a link to the Creative Commons license, and indicate if changes were made.

\section{References}

Balva, M., Legeai, S., Garoux, L., Leclerc, N., \& Meux, E. (2017). Dismantling and chemical characterization of spent Peltier thermoelectric devices for antimony, bismuth and tellurium recovery. Environmental Technology, 38(7), 791-797. https://doi.org/10.1080/09593330.2016.1211748.

Barbieri, N., \& Palma, A. (2017). Mapping energy-efficient technological advances in home appliances. Energy Efficiency, 10(3), 693-716.

Bonca, Z., \& Dziubek, R. (1994). Budowa i eksploatacja kontenerów chlodniczych [Construction and operation of refrigerated containers]. Gdynia: Wydawnictwo WSM Polish.

Chen, L. \& Notteboom, T. (2012). Distribution and value added logistics in the cold chain product market with application to the role of seaports. Paper presented at the Asian Logistics Round Table Conference (ALRT 2012), University of British Columbia (UBC), Vancouver, 14-15 June.

Defraeye, T., Verboven, P., Opara, U. L., Nicolai, B., \& Cronje, P. (2015). Feasibility of ambient loading of citrus fruit into refrigerated containers for cooling during marine transport. Biosystems Engineering, 134, 20-30. https://doi.org/10.1016/j. biosystemseng.2015.03.012.

Duan, H., Zhang, G., Fan, Y., \& Wang, S. (2017). Role of endogenous energy efficiency improvement in global climate change mitigation. Energy Efficiency, 10(2), 459-473.
European Commission, Joint Research Centre. (2016). Trends in global CO2 emissions. 2016 report. PBL Netherlands Environmental Assessment Agency. The Hague, http://edgar. jrc.ec.europa.eu/news_docs/jrc-2016-trends-in-global-co2emissions-2016-report-103425.pdf.

Filin, S., \& Chmielowski, M. (2015). Badania efektywności energetycznej współczesnych chłodziarek termoelektrycznych Część 3. Badania porównawcze chłodziarek Ravanson LK-48 oraz ChTT-48 [Research on energy efficiency of modern thermoelectric coolers Part 3. Comparative studies of Ravanson LK-48 and ChTT-48 refrigerators]. Chtodnictwo, 12, 22-25. Polish. https://doi.org/10.15199/8.2015.12.4.

Filin, S., \& Jasińska, B. (2013). Experimental investigations of two-level temperature controllers for transport thermoelectric refrigerators. Journal of Thermoelectricity, 5, 43-53.

Filin, S., \& Zakrzewski, B. (2000). Rosyjsko-ukraiński sprzeciw wobec protokołu montrealskiego. [Russian-Ukrainian opposition to the Montreal Protocol]. Technika chłodnicza $i$ klimatyzacyjna, 1, 9-13 Polish.

Filina, L., \& Filin, S. (2004). Some problems of overload and storage of refrigerating containers in the port territory. Archives of Transport, 1, 13-21.

Filina-Dawidowicz, L. (2014). Rationalization of servicing reefer containers in sea port area with taking into account risk influence. Polish Maritime Research, 21(2), 76-85. https://doi.org/10.2478/pomr-2014-0022.

Filina-Dawidowicz, L. \& Filin, S. 2016. Sposób zmniejszenia strat lub zysków ciepła sąsiadujących chłodniczych kontenerów z tadunkiem umieszczonych na placu składowym i zestawy do uszczelniania chtodniczych kontenerów z tadunkiem umieszczonych na placu sktadowym [A method to reduce heat losses or gains adjacent refrigerated containers with cooled cargo located on the storage yard and sets for sealing refrigerated containers with cargo located on the storage yard]. Patent Application nr 416025 from 04.02.2016. Polish.

Filina-Dawidowicz, L., \& Gajewska, T. (2018). Examination of importance and range of comprehensive service for refrigerated containers in seaports. International Journal of Applied Management Science (IJAMS), 10(1), 26-43.

Filina-Dawidowicz, L., \& Postan, M. Y. (2015). The directions of services development of European seaports specializing in handling perishable goods. Zeszyty naukowe Uniwersytetu Szczecińskiego seria "Ekonomiczne problemy ustug", 119, 85-98. https://doi.org/10.18276/epu.2015.119-06.

Fitzgerald, W. B., Howitt, O. J., Smith, I. J., \& Hume, A. (2011). Energy use of integral refrigerated containers in maritime transportation. Energy Policy, 39(4), 1885-1896. https://doi. org/10.1016/j.enpol.2010.12.015.

Geerlings, H., \& van Duin, R. (2011). A new method for assessing $\mathrm{CO}_{2}$-emissions from container terminals: a promising approach applied in Rotterdam. Journal of Cleaner Production, 19(6-7), 657-666. https://doi.org/10.1016/j. jclepro.2010.10.012.

He, J., Huang, Y., Yan, W., \& Wang, S. (2015). Integrated internal truck, yard crane and quay crane scheduling in a container terminal considering energy consumption. Expert Systems with Applications, 42(5), 2464-2487. https://doi.org/10.1016/j. eswa.2014.11.016.

Jasińska, B., \& Filin, S. (2012). Energetyczne charakterystyki transportowej chłodziarki termoelektrycznej w trybie 
dwupołożeniowej regulacji temperatury. Cześć 1. [Energy transfer characteristics of a thermoelectric cooler in a twoposition temperature control. Part 1.]. Chtodnictwo, 11, 6-10 Polish.

Jedermann, R., Geyer, M., Praeger, U., \& Lang, W. (2013). Sea transport of bananas in containers - parameter identification for a temperature model. Journal of Food Engineering, 115(3), 330-338. https://doi.org/10.1016/j.jfoodeng.2012.10.039.

Łukasik, Z., Kuśmińska-Fijałkowska, A., \& Nowakowski, W. (2015). Europe's energy efficiency requirements for household appliances. Przeglad elektrotechniczny, 3, 194-196. https://doi.org/10.15199/48.2015.03.45.

Maersk line: containers dimensions. (2017). http://www.maerskline. com/ /media/maersk-line/Countries/int/Files/used-containersales/maersk-line-equipment-guide.pdf [access: 25.05.2017].

Martins, J., Marques, R. C., Cruz, C. O., \& Fonseca, Á. (2017). Flexibility in planning and development of a container terminal: an application of an American-style call option. Transportation Planning and Technology, 40(7), 828-840. https://doi.org/10.1080/03081060.2017.1340026.

Polski Rejestr Statków. (2012). Przepisy budowy kontenerów [Container construction regulations]. Gdańsk. Polish.

Port Rotterdam official website. (2017). https://www. portofrotterdam.com/en/cargo-industry/containers/reefercontainers. Access 10 April 2017.

Reducing heat absorption of reefer containers, lowering energy consumption since. (2014). http://www.braintrustbase. $\mathrm{com} / \mathrm{sites} / \mathrm{default} / \mathrm{files} /$ upload-grafik/uploads/merged document_7.pdf. Access 20 April 2017.

Reefer container power consumption. (2017). http://www.ship. ru/konteyners/40_cube.php . Access 6 April 2017.

Ruiz-Garcia, L., Barreiro, P., Rodriguez-Bermejo, J., \& Robla, J. I. (2007). Review. Monitoring the intermodal, refrigerated transport of fruit using sensor networks. Spanish Journal of Agricultural Research, 5(2), 142-156.

Sørensen, K. K., Skovrup, M. J., Jessen, L. M., \& Stoustrup, J. (2015). Modular modeling of a refrigeration container. International Journal of Refrigeration, 55, 17-29. https://doi.org/10.1016/j.ijrefrig.2015.03.017.
Spengler, T. \& Wilmsmeier, G. (2016). Energy consumption and energy efficiency indicators in container terminals - a national inventory. Paper presented at IAME 2016 Conference, Hamburg, Germany, August 23 - 26.

Su, D. -T., Hsieh, C. -H., \& Tai, H. -H. (2016). Container hub-port vulnerability: Hong Kong, Kaohsiung and Xiamen. Journal of Marine Engineering \& Technology, 15(1), 19-30. https://doi.org/10.1080/20464177.2016.1140551.

Tassou, S. A., De-Lille, G., \& Ge, Y. T. (2009). Food transport refrigeration - approaches to reduce energy consumption and environmental impacts of road transport. Applied Thermal Engineering, 29(8-9), 1467-1477.

Wilmsmeier, G., Froese, J., Zotz, A. K., \& Meyer, A. (2014). Energy consumption and efficiency: emerging challenges from reefer trade in South American container terminals. FAL Bulletin, 329(1), 1-17.

Yang, Y.-C., \& Lin, C.-L. (2013). Performance analysis of cargohandling equipment from a green container terminal perspective. Transportation Research Part D: Transport and Environment, 23, 9-11. https://doi.org/10.1016/j.trd.2013.03.009.

Zakrzewski, B. (2007). Odszranianie oziębiaczy powietrza [Air coolers defrosting]. Warszawa: WNT Polish.

Zakrzewski, B. (Ed.). (2015). Chłodnictwo i klimatyzacja [Refrigeration and air conditioning]. Tom I. Odessa: Astroprint Polish.

Правила расчета потенциала энергосбережения. СРОПР НП СЭЭ ТЭРО13-2014 [Rules for calculating the energy saving potential]. Казань, 2014. Russian, https://www.google. $\mathrm{pl} / \mathrm{url}$ ? sa $=\mathrm{t} \& \mathrm{rct}=\mathrm{j} \& \mathrm{q}=\& \mathrm{esrc}=\mathrm{s} \&$ source $=\mathrm{web} \& \mathrm{~cd}=8 \& \mathrm{cad}=$ rja\&uact $=8 \&$ ved $=0$ ahUKEwiU6eufvrXQAhWC2SwKHbgCMEQFghNMAc\&url=http $\% 3 \mathrm{~A} \% 2 \mathrm{~F} \% 2 \mathrm{~F} x \mathrm{n} \% 2 \mathrm{D} \% 2 \mathrm{D} \% 2$ D\%2Dctbfebrf1bzabeme 8m.xn\%2D\%2Dp 1ai\%2 Ffilemanager\%2Fdownload\%2F474\&usg=AFQjCNELk1 RVDGK 60 A D M DbE o go Q Q oU Q N p w \& b v m = bv.139250283,d.bGg [access: 20.02.2017].

Фокин, К. Ф. (2006). Строительная теплотехника ограждаюших частей зданий [Building heat engineering of enclosing parts of buildings]. 5-е издание. Авок-пресс Russian. 